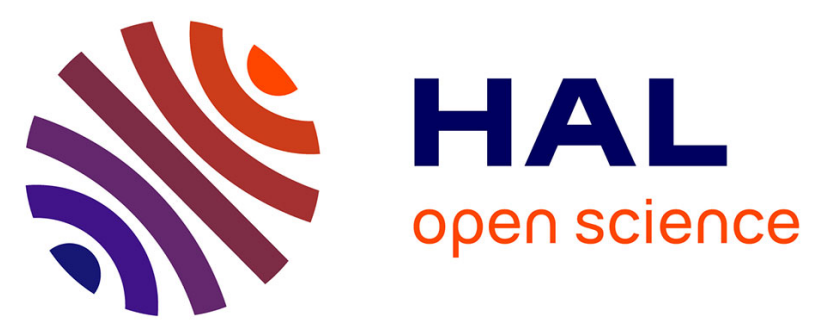

\title{
A potential robust antiviral defense state in the common vampire bat: Expression, induction and molecular characterization of the three interferon-stimulated genes -OAS1, ADAR1 and PKR
}

Sarkis Sarkis, Stéphanie Dabo, Marie-Claude Lise, Christine Neuveut, Eliane

Meurs, Vincent Lacoste, Anne Lavergne

\section{To cite this version:}

Sarkis Sarkis, Stéphanie Dabo, Marie-Claude Lise, Christine Neuveut, Eliane Meurs, et al.. A potential robust antiviral defense state in the common vampire bat: Expression, induction and molecular characterization of the three interferon-stimulated genes -OAS1, ADAR1 and PKR. Developmental and Comparative Immunology, 2018, 85, pp.95-107. 10.1016/J.DCI.2018.04.006 . pasteur-02197397

\section{HAL Id: pasteur-02197397}

https://hal-riip.archives-ouvertes.fr/pasteur-02197397

Submitted on 6 Apr 2020

HAL is a multi-disciplinary open access archive for the deposit and dissemination of scientific research documents, whether they are published or not. The documents may come from teaching and research institutions in France or abroad, or from public or private research centers.
L'archive ouverte pluridisciplinaire HAL, est destinée au dépôt et à la diffusion de documents scientifiques de niveau recherche, publiés ou non, émanant des établissements d'enseignement et de recherche français ou étrangers, des laboratoires publics ou privés. 
1 A potential robust antiviral defense state in the common vampire bat: expression, 2 induction and molecular characterization of the three interferon-stimulated genes -

3 OAS1, ADAR1 and PKR

5 Sarkis Sarkis ${ }^{a, *}$, Stéphanie Dabo ${ }^{b}$, Marie-Claude Lise ${ }^{a}$, Christine Neuveut ${ }^{b}$, Eliane F.

6 Meurs $^{\mathrm{b}}$, Vincent Lacoste ${ }^{\mathrm{a}}$ and Anne Lavergne ${ }^{\mathrm{a}, \text { * }}$

7

8 a Laboratoire des Interactions Virus-Hôtes, Institut Pasteur de la Guyane, Cayenne, French

9 Guiana

10

$11{ }^{\mathrm{b}}$ Hepacivirus and Innate Immunity, Institut Pasteur, 75015 Paris, France

12

$13 *$ Corresponding authors.

14 Laboratoire des Interactions Virus-Hôtes, Institut Pasteur de la Guyane, 23 avenue Pasteur, 1597300 Cayenne, French Guiana.

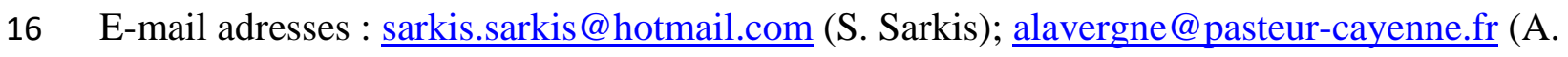

17 Lavergne)

18

19 Keywords: Desmodus rotundus, Innate immunity, ISGs, OAS1a, OAS1b, ADAR1, PKR

20 


\section{Abstract}

Bats are known to harbor many zoonotic viruses, some of which are pathogenic to other mammals while they seem to be harmless in bats. As the interferon (IFN) response represents the first line of defense against viral infections in mammals, it is hypothesized that activation of the IFN system is one of the mechanisms enabling bats to co-exist with viruses. We have previously reported induction of type I IFN in a cell line from the common vampire bat, Desmodus rotundus, upon polyinosinic:polycytidylic acid (poly(I:C)) stimulation. To deepen our knowledge on $D$. rotundus' IFN-I antiviral response, we molecularly characterized three interferon-stimulated genes (ISGs), $O A S 1, P K R$ and $A D A R 1$, closely implicated in the IFN-I antiviral response, and tested their functionality in our cellular model. We first found that $D$. rotundus encoded two OASI paralogs, OASIa and OASIb, and that the functional domains of the four ISGs characterized were highly conserved with those of other mammals. Despite their significant transcription level in the absence of stimulation, the transcription of the four ISGs characterized was enhanced by poly(I:C). In addition, the transcription of OAS1a and OAS1b appears to be differentially regulated. These findings demonstrate an active ISG antiviral response in $D$. rotundus in which OAS1b may play an important role.

\section{Highlights}

- Four ISGs implicated in the antiviral response were molecularly characterized.

- Two OAS1 paralogs were characterized in D. rotundus.

- The functional domains of the characterized ISGs are highly conserved relative to their mammalian homologs.

- Significant induction of Oas1b was observed after stimulation with poly(I:C). 


\section{Introduction}

The interferon (IFN)-mediated innate immune response provides a robust first line of defense against invading pathogens. Pathogen-associated molecular patterns' (PAMP) recognition by pattern recognition receptors (PRRs) leads to a subsequent production of IFN, especially of types I (IFN $\alpha / \beta)$ and III (IL28A, IL28B, IL29), considered as the main antiviral IFNs (Borden et al., 2007). Newly synthesized IFN molecules up-regulate the transcription of hundreds of interferon-stimulated genes (ISGs) resulting in the production of various antiviral effectors (Der et al., 1998). This cascade leads to a remarkable antiviral state of infected and neighboring cells and limits the spread of infectious agents. Considering the large number of ISGs activated upon IFN signaling, considerable redundancy in the system is likely. Among the molecules with important biological functions induced by IFN are the $2^{\prime} 5^{\prime}$ oligoadenylate synthetase/ribonuclease L (OAS/RNase L) system, the adenosine deaminase RNA-specific (ADAR) as well as the dsRNA-activated protein kinase (PKR), which play a critical role in the host's antiviral defense mechanism and are among the most extensively studied ISGs (Der et al., 1998; George and Samuel, 1999; Levy et al., 2002; Sen, 2001). Even though the specific functions of mammalian OAS1, ADAR and PKR have yet to be clarified, their structural (architectural) domain organizations are well characterized and show a high degree of similarity among species.

The $O A S$ gene family comprises three classes of genes in human, OAS1, OAS2 and OAS3, in addition to an "OAS-like" (OASL), which is catalytically inactive. The mouse $O A S$ cluster, the second most well known after the human $O A S$ cluster, contains one $O A S 2$ and one OAS3 gene; two OASLs, of which one is a pseudogene; and eight paralogs of OAS1, Oas1a-Oaslh (Kristiansen et al., 2011). Activation of the OAS proteins in presence of single-stranded (ss) or double-stranded (ds) RNA triggers the synthesis of 2'5' oligoadenylates. These in turn bind to and activate the latent RNaseL, which restricts viral propagation through direct and indirect 
mechanisms, including i) viral genome degradation (RNA and DNA), ii) cellular mRNA degradation, including mitochondrial RNA followed by apoptosis, as well as iii) amplification of IFN signaling through the release of additional PAMPs activating cytoplasmic helicases, which in turn activate type I IFN synthesis and create a positive feedback loop (Justesen et al., 2000; Malathi et al., 2007, 2005; Silverman, 2003; Xiang et al., 2003). Regarding its domain organization, on its N-terminus OAS1 comprises a nucleotidyl transferase domain (NTPtransf_2) constituted of a dsRNA-binding domain flanked by two ATP-binding domains, which plays a critical role in OAS1 activation. On its C-terminus, OAS1 presents the OAS1_C domain including the region of enzymatic activity thought to activate latent RNAseL (Sarkar et al., 2002).

ADAR belongs to a family of proteins that modulate nucleic acid integrity and play an important role in the defense against viral RNAs. All ADAR family members present doublestranded RNA-binding domains (dsRBDs) at their N-termini and a catalytic deaminase domain located at their C-termini (Mannion et al., 2015). A unique feature of ADAR1, when compared to other members of the ADAR family, is the presence of Z-DNA-binding domains (ZBDs) at its N-terminus with a Z $\alpha$ and a $Z \beta$ domain (Kim et al., 1999). In addition to the capacity of the Z $\alpha$ domain to bind to Z-DNA/RNA (Herbert et al., 1997), it has been reported that all proteins containing this domain are implicated in the type I IFN response pathway (Athanasiadis et al., 2005). Furthermore, the $\mathrm{Z} \alpha$ domain is essential for the location of ADAR1 to cytoplasmic stress granules following activation. Upon binding to dsRNA, ADAR1 induces editing of adenosine to inosine, one of the most abundant modifications of mammalian RNA (Bazak et al., 2014; Goodman et al., 2012). However, depending on the viral species, the editing event can make ADAR1 act as either a proviral or an antiviral factor. Indeed, whereas editing by ADAR1 of lymphocytic choriomeningitis virus introduces mutations in viral proteins and reduces infectivity, editing of HIV-1 rev and tat proteins leads 
to increased infectivity (Doria et al., 2009). In addition, ADAR1 can also exert a proviral function through its Z-DNA and dsRBD domains by interacting with PKR, another dsRBDcontaining protein. Such interaction negatively regulates the antiviral function of PKR (Clerzius et al., 2009).

PKR (protein kinase dsRNA-dependent) is one of the four eIF-2 $\alpha$ serine-threonine kinases that controls protein synthesis through the phosphorylation of the alpha subunit of eukaryotic initiation factor 2 (eIF-2 $\alpha$ ). PKR is ubiquitously expressed and can be induced upon IFN treatment (Meurs et al., 1990, 1992; Williams, 2001). PKR becomes activated upon binding to dsRNA, as during viral infection, or to cellular activators in response to stress (Dabo and Meurs, 2012). Because of PKR's role in controlling protein synthesis, it can inhibit infection by a number of viruses. Nevertheless, other viruses, such as the hepatitis $\mathrm{C}$ virus, benefit from the general shut-down of protein synthesis, which promotes their own eIF-2 $\alpha$-independent translation (Arnaud et al., 2010; Garaigorta and Chisari, 2009). In addition, PKR modulates signaling pathways involved in inflammation independently of its enzymatic activity (Bonnet et al., 2006; García et al., 2007). PKR consists of two functionally distinct domains: a Nterminal dsRNA binding regulatory domain (dsRBD) and a C-terminal kinase catalytic domain. The dsRNA-binding domain contains two dsRNA-binding motifs (dsRBMs). These motifs are rich in basic residues and confer to PKR the capability of binding to dsRNA independently of the sequence. As a member of the kinase proteins, PKR presents all the conserved catalytic kinase subdomains. In addition, the homology within subdomain VI identifies PKR as a serine/threonine kinase (Meurs et al., 1990). PKR also possesses an insert region C-terminal of Domain IV. This insert region and the dsRBD are key determinants of the PKR function and regulation.

Bats are known to harbor many zoonotic viruses, some of which are pathogenic to other mammals while they seem to be harmless or only rarely associated with clinical signs in bats 
(Moratelli and Calisher, 2015). Strikingly, mechanisms that allow bats to coexist with these viruses have not yet been fully researched. It is currently acknowledged that early control of viral replication by their innate immune system might be one of the mechanisms implicated, enabling bats to coexist with viruses (Baker et al., 2013). Following the establishment of a Desmodus rotundus cell line, FluDero, and the molecular characterization of the RIG-I-like receptor members and of type I interferons (Sarkis et al., 2018), we studied several ISGs from this bat species given that they are responsible for the antiviral activity of IFNs in mammals (Der et al., 1998; He et al., 2014; Levy et al., 2002; Sen, 2001; Zhou et al., 2013). Here, we describe the molecular characterization of three ISGs, OASI, ADARI and PKR, from Desmodus rotundus and report differential expression profiles for these genes upon stimulation of the FLuDero fetal lung cell line with the synthetic analog of dsRNA, the polyinosinic:polycytidylic acid, poly(I:C).

\section{Materials and Methods}

\subsection{Cell line, cell culture and poly(I:C) stimulation}

Establishment of the FluDero cell line has been described previously (Sarkis et al., 2018). The cell line was cultured in prewarmed DMEM/Ham's Nutrient Mixture F12 (Sigma) supplemented with $10 \%$ fetal bovine serum (FBS) (Sigma), 100 units/mL penicillin and 100 $\mu \mathrm{g} / \mathrm{mL}$ streptomycin and was maintained in a humidified incubator with $5 \% \mathrm{CO}_{2}$ at $37^{\circ} \mathrm{C}$. For poly(I:C) stimulation, FLuDero cells were seeded at a density of $2.5 \times 10^{5}$ cells/well in 12 -well plates. Cells were stimulated by transfection with $20 \mu \mathrm{g} / \mathrm{mL}$ of poly(I:C) (Sigma, cat \#P9582) by calcium phosphate transfection (Invitrogen), $20 \mathrm{~h}$ after seeding. Cells were harvested in TRIzol Reagent at $0,3,6,9,12,24,48$ and $72 \mathrm{~h}$ post-transfection and stored at $-80^{\circ} \mathrm{C}$ until RNA extraction. The experiment was performed three times.

\subsection{RNA extraction and cDNA synthesis}


Reagent (Invitrogen) as recommended by the manufacturer. cDNAs were synthesized using Superscript ${ }^{\circledR}$ III reverse transcriptase (Invitrogen) and random hexamers following the manufacturer's instructions.

\subsection{Sequence identification and domain characterization of OAS1, ADAR1 and PKR}

To generate the full-length coding sequences of $O A S 1, A D A R l$ and $P K R$, all amplifications were performed on cDNA obtained from poly(I:C)-transfected FluDero cells. Internal coding regions were amplified by PCR using the AmpliTaq Gold DNA polymerase kit (Thermo Fischer Scientific). Different combinations of consensus and specific degenerate primers were designed using Primer3 (v.0.4.0) based on alignments of orthologous mammal sequences, which were available in the GenBank database (Supplementary Table 1). The 5'and 3'-terminal sequences were obtained by rapid amplification of cDNA ends (RACE) using the FirstChoice ${ }^{\circledR}$ RLM-RACE Kit (Ambion, Inc.). PCR and RACE products were cloned using the $\mathrm{pCR}^{\mathrm{TM}} 4-\mathrm{TOPO}^{\circledR} \mathrm{TA}$ CLONING ${ }^{\circledR} \mathrm{KIT}$ (Invitrogen). The sequences obtained were confirmed by similarity analysis using the NCBI BLAST search tool (http://www.ncbi.nlm.nih.gov/BLAST). The structural domains of each protein were identified using SMART software (http://smart.embl-heidelberg.de/) (Letunic et al., 2015). Multi-alignment was performed with the ClustalW program (https://npsa-prabi.ibcp.fr/cgibin/npsa_automat.pl?page=/NPSA/npsa_clustalw.html) using default parameters.

\subsection{Phylogenetic analysis}

The complete coding sequences for ADARI and PKR of 18 and 17 representatives Laurasiatherian and Euarchontoglires, respectively, were downloaded from the NCBI database. Available sequences included those from the bat species Eptesicus fuscus, Miniopterus natalensis, Myotis brandtii, Myotis davidii, Myotis lucifugus, Pteropus alecto, 

Pteropus vampyrus, Rhinolophus sinicus and Rousettus aegyptiacus (Supplementary Table 2). The ISG sequences of $D$. rotundus obtained in this study were further added to each data set. After alignment and editing, the MEGA version 6.0 software (Tamura et al., 2013) was used to compute pairwise comparisons in the nucleotide and amino acid using uncorrected pdistances. The best-fit amino acid evolutionary substitution model (Jones-Taylor-Thornton + $\mathrm{G}+\mathrm{F}$ ) was determined using MEGA version 6.0. Bayesian phylogenetic analyses were performed using MrBAYES 3. Markov Chain Monte Carlo (MCMC) simulations were run for 10,000,000 generations, with four simultaneous chains, using a sample frequency of 500 and a burn-in of 25,000. Majority rule consensus trees were obtained from the output. Validation of the inference was assessed based on the standard deviation of split frequencies, which was less than the expected threshold value of 0.01 (calculated value of 0.002 ). ADAR1 and PKR trees were rooted with the rodent Mus musculus sequences. Coding sequences from 33 representative mammalian species retrieved in NCBI were used for OAS1 pairwise comparisons and phylogenetic analysis (Supplementary Table 2). Eight corresponded to the bat species E. fuscus (two paralogs), M. natalensis (two paralogs), M. brandtii (two paralogs), M. davidii, M. lucifugus (two paralogs), P. alecto, P. vampyrus and R. aegyptiacus. An OAS1 tree was constructed based on the alignment of amino acid residues and was rooted with OASL sequences from $M$. natalensis, $P$. alecto, $P$. vampyrus and $R$. aegyptiacus.

\subsection{Quantitative PCR}

Quantitative PCR (qPCR) was performed on a StepOne ${ }^{\mathrm{TM}}$ Real-Time PCR System using the TaqMan® Universal PCR Master Mix (Applied Biosystems). Primers and TaqMan® probes were designed using Primer Express 3.0 (Applied Biosystems) (Supplementary Table 1). Each reaction was performed in duplicate. The cycling conditions were those recommended by the manufacturer: $55^{\circ} \mathrm{C}$ for $2 \min , 95^{\circ} \mathrm{C}$ for $2 \min$ followed by 40 cycles at $95^{\circ} \mathrm{C}$ for $15 \mathrm{~s}, 60^{\circ} \mathrm{C}$ for $1 \mathrm{~min}$. For absolute quantification, the exact number of copies of the 
gene of interest was calculated using a plasmid DNA standard curve. Individual expression values were normalized and compared to mRNA encoding $\beta$-actin. Values are shown graphically as fold induction compared to the mock sample $(0 \mathrm{~h}$ transfection $)$ for each experiment.

\section{Results}

\subsection{Sequence characterization of D. rotundus OASla, OAS1b, ADARI and PKR genes}

Primers derived from alignments of the orthologous mammalian $O A S 1, A D A R 1$ and PKR sequences were used to characterize $O A S 1, A D A R 1$ and $P K R$ genes from mRNA extracted from the FluDero cell line. The full-length coding sequences for $A D A R 1$ and $P K R$ were identified. Sequence analysis revealed that their coding regions were 3444 and 1611 base pairs (bp) long, respectively, encoding proteins of 1149 and 537 amino acids (aa), respectively. In addition, we characterized two $O A S 1$ paralog genes in D. rotundus, which we named OASI $a$ and OASIb. The partial coding sequence of OASla was 1056 bp in length (352 aa). On the other hand, the complete coding region of $O A S 1 b$ was $1101 \mathrm{bp}$ long encoding a 367-aa protein. When comparing the OASIa and OASIb with their mammalian counterparts, OASla seems to lack 17 aa at its C-terminal.

Pairwise comparison done on 897 nucleotides corresponding to 299 amino acid residues showed that the two OAS1 paralogs shared 81.6 and $77.3 \%$ of sequence identity at the nucleotide and amino acid levels, respectively. However, when compared to their mammalian homologs, OASla showed a higher level of sequence identity at the nucleotide and amino acid levels than OASIb. For instance, OASIa exhibited $84 \%$ and $80 \%$ identity at the nucleotide and amino acid levels, respectively, and $O A S 1 b$ shared 78 and $73 \%$ identity with the OAS1 sequence of the Pteropus species. In the same way, OASla shared 73-80\% amino acid identity with its equine, canine, bovine and human homologs, while $O A S 1 b$ presented 69- 
75\% sequence identity (Supplementary Table 3). D. rotundus' $A D A R I$ and $P K R$ were also subjected to pairwise comparison with their mammalian homologs. Among the four ISGs characterized, the complete amino acid sequence of $A D A R l$ displayed the highest level of sequence identity with its mammalian counterparts, while $P K R$ shared the lowest. For instance, ADAR1 and PKR displayed $85.4-89.6 \%$ and $64.7-71 \%$ sequence identity at the protein level with their bat homologs, respectively (Supplementary Table 3). In addition, when comparing $D$. rotundus $P K R$ with other mammalian homologs the identity at the protein level was slightly lower.

\subsection{Conserved domain organization in D. rotundus ISGs}

One of the hallmarks of the ISGs is their domain architecture responsible for their function. Sequence analysis of the two OAS1 paralogs identified in D. rotundus using the SMART software showed that these two proteins presented a similar structural domain organization to that described in their mammalian homologs. They possess the two characteristic functional domains of OAS1, i.e., the NTP-transf_2 domain on their N-termini and C-terminal OAS1_C domain. These domains are located between aa 36-121 and 162345, respectively (all values are given relative to $H$. sapiens sequences) (Figure 1). The $D$. rotundus OAS1a and OAS1b putative proteins showed conservation of the hallmark motifs crucial for OAS1 activity, i.e., the LxxxP sequence required for enzymatic activity, a P-Loop motif with a $(\mathrm{G}[\mathrm{G} / \mathrm{S}] \mathrm{xx})$ sequence, which precedes the first triad residue corresponding to the second signature of the nucleotidyl transferase superfamily formed by Asparagine residues (represented with an inverted triangle), a K-R rich region and a CFK motif located in the Cterminal domain (Figure 1). Similarly, the D. rotundus ADAR1 protein contained all domains necessary for its function, including at its N-terminus the two $\mathrm{Z} \alpha$ domains, a central dsRBD with three dsRBM, and a catalytic deaminase domain at its C-terminus. These domains and motifs are located between aa 132-202, 291-360, 504-569, 615-680, 727-793 and 840- 
1222, respectively (Figure 2a). Finally, the deduced protein sequence of $D$. rotundus PKR showed the conservation of all domains relative to its function including the $\mathrm{N}$-terminus dsRBD with the two dsRBM (dsRBM1 and dsRBM2) between aa 9-81 and 102-169 (yellow and light gray boxes, respectively) and all subdomains (open boxes) in the catalytic region. A variable region was also found in D. rotundus PKR between the dsRBM2 and the basic region (in dark gray) between aa 229 and 251. In addition, D. rotundus PKR presented a conserved insert region at the C-terminal of subdomain IV (blue) between aa 362 and 370. However, $D$. rotundus PKR did not possess the repeat sequence (green) found in the catalytic region of the human PKR, a common feature observed in other bat species and mice (Figure 2b).

\subsection{The D. rotundus-characterized ISGs are closely related to their mammalian counterparts}

To elucidate the evolutionary relationships of OAS1a and OAS1b, ADAR1 and PKR, phylogenetic trees were constructed based on multiple amino acid alignments constructed with other published mammal sequences (Figure 3). The OAS1 phylogenetic topology obtained was in agreement with the different mammalian orders, showing that OAS1a and OAS1b from $D$. rotundus belonged to a single clade of chiropters. Within this clade, OAS1a and OAS1b clustered with OAS1-like and OAS1 of microbats, respectively, and were supported with high posterior probability values (Figure 3a). On the other hand, the phylogenetic analyses of ADAR1 (Figure 3b) and PKR (Figure 3c) showed that all bat sequences belonged to a clade distinct from other mammal species, with the microbats $(D$. rotundus, M. natalensis, E. fuscus and Myotis species) diverging from the megabats (Pteropus species, $R$. aegyptiacus, and $R$. sinicus).

\subsection{D. rotundus OAS1, ADARI and PKR can be induced in response to poly(I:C) stimulation}

To investigate the functionality of these ISGs in FLuDero, we studied their expression profile after poly(I:C) transfection (Figure 4). The kinetics of the expression of OAS1a, 
266 OAS1b, ADAR1 and PKR mRNA revealed a similar induction profile. The induction was 267 observed $6 \mathrm{~h}$ post-transfection, reaching a peak at $24 \mathrm{~h}$ followed by a decline at $48 \mathrm{~h}$. Among 268 the ISGs studied, OAS1b was the most inducible gene (400-fold up-regulation at $24 \mathrm{~h}$ ) at all 269 time points of the kinetics. In contrast, $A D A R I$ and $P K R$ were the least induced genes, 270 showing a peak of induction at $24 \mathrm{~h}$ with a 15- and nine-fold induction, respectively. 271 Strikingly, in the absence of stimulation, transcription of the four ISGs characterized was 272 already significant, with a strong expression of PKR mRNA (Figure 5, 0 hrs). 


\section{Discussion}

275

276

277

278

279

280

281

282

Viral infection in mammals often triggers the IFN-I-mediated frontline host defense mechanism, leading to the transcription of a wide range of ISGs (Randall and Goodbourn 2008). These ISGs confer an antiviral state to the host and neighboring cells by several mechanisms, including inhibition of viral transcription, translation and replication, as well as degradation of viral nucleic acids. We previously demonstrated that FLuDero cells were competent to mount high levels of IFN-I after transfection with poly(I:C) (Sarkis et al., 2018). To deepen our understanding of the D. rotundus' IFN-I antiviral response, we molecularly characterized three ISGs, $O A S 1, P K R$ and $A D A R 1$, closely implicated in the IFN-I antiviral response and looked at their expression upon poly(I:C) stimulation of FLuDero cells.

Contrary to other mammals such as in human, which only possesses one $O A S 1$ gene, we characterized two $O A S 1$ paralogs $(O A S 1 a$ and $O A S 1 b)$ in $D$. rotundus, a feature shared with some bat species such as Myotis lucifigus, M. natalensis and E. fuscus, and other mammals such as the mouse, which has several OAS1 paralogs. Nevertheless, even if the mouse expresses eight OAS1 genes, only two (OAS1a and OAS1g) conserve their activities (Elkhateeb et al., 2016). The other paralogs are non-functional due to mutations or deletions of at least one of their functional domains. Multiple sequence alignment of D. rotundus $O A S I a$ and $O A S I b$ with their mammalian ortholog sequences demonstrated that they have the same structural organization and are thus likely to possess similar enzymatic and antiviral activities. For instance, the P-Loop motif, which is an ATP-binding site (Saraste et al., 1990; Tag-El-Din-Hassan et al., 2012), the DAD motif in D box, which is a $\mathrm{Mg}^{2+}$-binding site (Sarkar et al., 2002; Yamamoto et al., 2000), the KR-rich region, which is an oligoadenylate and ATP-binding site (Marié et al., 1997), and the CFK motif located in the C-terminal domain, required for the tetramerization of the proteins, are all conserved (Ghosh et al., 1997). In a previous study on $P$. alecto, Zhou and colleagues characterized a single OAS1 gene. 
However, they did not exclude the possible existence of additional OAS1 paralogs given that their analysis was based on a $P$. alecto genome assembly not fully achieved at the time of the study (Zhou et al., 2013). In the database, many bat OAS1 genes have been annotated as "OAS1-like" such as in M. lucifigus, P. vampyrus, M. natalensis and E. fuscus. However, these genes do not show any mutation on their functional sites, which could result in a loss of function ( Guénet et al. 2015). Moreover, the OAS1 phylogenetic tree reveals that some bat OAS1 and OAS1-like sequences are intermixed within different clades (Fig. 3a). A consensus on "OAS1" naming is therefore needed. In this regard, the generation of more OAS1 sequences from other bat species should extend our understanding of their evolutionary history.

The molecular characterization and domain prediction of PKR show that the regulatory and kinase subdomains of the D. rotundus' PKR protein are remarkably conserved with respect to those of other mammals. For instance, the N-terminal domain of D. rotundus' PKR includes a repeated motif (dsRBD) that possesses dsRNA-binding activity and the C-terminal half of PKR includes the 11 conserved catalytic subdomains characteristic of kinases. Our multiple sequence alignment of mammals' PKR shows the conservation of the major residues crucial to the function of the protein such as the highly conserved lysine $\mathrm{K}^{64}$ of the RNAbinding domain required for its RNA-binding activity, the $\mathrm{K}^{296}$ in the catalytic subdomain II required for its kinase activity and the $\mathrm{T}^{446}$ within the activation loop that confers to PKR its specificity as a serine/threonine kinase (Dabo and Meurs, 2012). In addition, the salt bridge interaction of $\mathrm{R}^{262}$ and $\mathrm{D}^{266}$ at the dimer interface of PKR, which is critical to eIF2 $\alpha$ phosphorylation and PKR activation, is also conserved (Dey et al., 2007).

Similarly, depending on the sequence alignment, ADAR1 is also highly conserved with those of other mammals. For instance, we found that residues $\mathrm{H}^{910}$ and $\mathrm{E}^{912}$ of the CHAE motif, considered as a key element of the catalytic core characteristic of deaminases, are 
conserved. It has been shown that their mutations completely abolish A-to-I editing activity (Lai et al., 1995; Liu and Samuel, 1996). Further, $C^{966}$ and $C^{1036}$, which are believed to play a role in zinc coordination along with $\mathrm{H}^{910}$, are necessary for ADAR1 deaminase activity and are also conserved in D. rotundus (Lai et al., 1995). Moreover, as in other mammals, the lysine residues crucial for both RNA binding and enzymatic activity, present in the core sequence of each of the dsRBD domains $\left(\mathrm{K}^{554}, \mathrm{~K}^{665}\right.$, and $\left.\mathrm{K}^{777}\right)$ are conserved (Fierro-Monti and Mathews, 2000; Liu and Samuel, 1996; McCormack et al., 1994).

To test the functionality of the ISG system upon viral infection in our bat model, expression of the characterized ISGs was examined following transfection of FLuDero cells with poly(I:C). The induction profile of the ISGs characterized in our bat model does not match that obtained by Zhou and colleagues (Zhou et al., 2013) on lung cells from P. alecto after poly(I:C) transfection. Although we also showed an induction of OAS1 and PKR following poly(I:C) transfection, they found higher and earlier induction of PKR as compared to OAS1. The discrepancy between this previous study and our results is probably due to intrinsic factors specific to the bat species leading to distinct expression profiles. Indeed, it has recently been reported that the up-regulation of ISGs was not only lineage- but also species-specific when comparing the megabats and the microbats (Shaw et al., 2017). In addition, the higher induction of OAS1a and OAS1b, as compared to ADAR1 and PKR, may be due to the presence of multiple IFN-stimulated response elements (ISREs) in the OAS1 promoter, as described in P. alecto (Zhou et al., 2013). This can conveniently allow bats to mount a more robust expression of OAS1 rather than of ADAR1 or PKR. In fact, we previously showed an induction of expression of IFN $\beta$ in poly(I:C)-transfected FLuDero, reaching a peak at $24 \mathrm{~h}$ (Sarkis et al., 2018). Interestingly, the expression kinetics of the three ISGs characterized was similar to that of IFN $\beta$, suggesting that these proteins are induced in an IFN $\beta$-dependent manner, acting on the ISREs present in their promoters. It is conceivable that the similar 
expression levels of ADAR and PKR observed at the RNA level are also observed at the protein level. Accordingly, given the negative regulation of PKR by ADAR, as indicated above, an active PKR might not be in sufficient quantity to exert a proper antiviral action. Therefore, the higher induction of OAS observed, as compared to PKR and ADAR, tends to show the particular importance of the OAS proteins in the antiviral action of IFN in bats. Another interesting observation was the differential expression of OAS1a and OAS1b in our cellular model after poly(I:C) transfection. Interestingly, this feature has already been described in mice (Pulit-Penaloza et al., 2012). It has been shown that the ISRE as well as the overlapping STAT sites are required for Oas 1a promoter induction by IFN- $\beta$ while Oas $1 \mathrm{~b}$ expression requires only the ISRE. Furthermore, while OAS1a requires both STAT1 and STAT2 for its upregulation by IFN- $\beta$, OAS1b only requires STAT2. Therefore, analyzing the promoter region of these two paralogs should clarify their differential expression in our bat species.

We found that the basal transcription level of the ISGs characterized was elevated in the FLuDero cells. This observation is consistent with previous results showing that ISGs are constitutively expressed in bats and suggests that bat cells are equipped to mount a rapid defense against viral infections (Cruz-Rivera et al., 2018; Shaw et al., 2017; Zhou et al., 2016). In addition to their already significant levels of expression in the absence of treatment, these ISGs can be further enhanced in response to poly(I:C). Together these results tend to prove that these ISGs are functional and must play an important antiviral role in D. rotundus. Further work is therefore necessary to elucidate their role during viral infection, explore the mechanisms underlying their unique expression profiles and determine whether or not they contribute to the unique ability of bats to manage viral infection. 
374 This study was conducted within the CAROLIA and BATIMMUNE programs. CAROLIA 375 was supported by European funds (ERDF/FEDER) and assistance from the Région Guyane 376 and the Direction Régionale pour la Recherche et la Technologie. BATIMMUNE was funded 377 by the Institut Pasteur through a Transversal Research Program (PTR499). This study also 378 received a European Commission "REGPOT-CT-2011-285837-STRonGer" grant within the 379 FP7 and an "Investissement d'Avenir" grant managed by the Agence Nationale de la 380 Recherche (CEBA, Ref. ANR-10-LABEX-25-01). The funders had no role in study design, 381 data collection and analysis, decision to publish, or preparation of the manuscript.

383 Competing Interests

384 The authors declare that they have no competing interests. 


\section{References}

Arnaud, N., Dabo, S., Maillard, P., Budkowska, A., Kalliampakou, K.I., Mavromara, P., Garcin, D., Hugon, J., Gatignol, A., Akazawa, D., Wakita, T., Meurs, E.F., 2010. Hepatitis C Virus Controls Interferon Production through PKR Activation. PLoS ONE 5. https://doi.org/10.1371/journal.pone.0010575

Athanasiadis, A., Placido, D., Maas, S., Brown, B.A., Lowenhaupt, K., Rich, A., 2005. The Crystal Structure of the Z $\beta$ Domain of the RNA-editing Enzyme ADAR1 Reveals Distinct Conserved Surfaces Among Z-domains. J. Mol. Biol. 351, 496-507. https://doi.org/10.1016/j.jmb.2005.06.028

Baker, M.L., Schountz, T., Wang, L.-F., 2013. Antiviral immune responses of bats: a review. Zoonoses Public Health 60, 104-116. https://doi.org/10.1111/j.1863-2378.2012.01528.x

Bazak, L., Haviv, A., Barak, M., Jacob-Hirsch, J., Deng, P., Zhang, R., Isaacs, F.J., Rechavi, G., Li, J.B., Eisenberg, E., Levanon, E.Y., 2014. A-to-I RNA editing occurs at over a hundred million genomic sites, located in a majority of human genes. Genome Res. 24, 365-376. https://doi.org/10.1101/gr.164749.113

Bonnet, M.C., Daurat, C., Ottone, C., Meurs, E.F., 2006. The N-terminus of PKR is responsible for the activation of the NF- $\mathrm{BB}$ signaling pathway by interacting with the IKK complex. Cell. Signal. 18, 1865-1875. https://doi.org/10.1016/j.cellsig.2006.02.010

Borden, E.C., Sen, G.C., Uze, G., Silverman, R.H., Ransohoff, R.M., Foster, G.R., Stark, G.R., 2007. Interferons at age 50: past, current and future impact on biomedicine. Nat. Rev. Drug Discov. 6, 975-990. https://doi.org/10.1038/nrd2422

Clerzius, G., Gélinas, J.-F., Daher, A., Bonnet, M., Meurs, E.F., Gatignol, A., 2009. ADAR1 Interacts with PKR during Human Immunodeficiency Virus Infection of Lymphocytes and Contributes to Viral Replication. J. Virol. 83, 10119-10128. https://doi.org/10.1128/JVI.02457-08

Cruz-Rivera, P.C.D.L., Kanchwala, M., Liang, H., Kumar, A., Wang, L.-F., Xing, C., Schoggins, J.W., 2018. The IFN Response in Bats Displays Distinctive IFN-Stimulated Gene Expression Kinetics with Atypical RNASEL Induction. J. Immunol. 200, 209-217. https://doi.org/10.4049/jimmunol.1701214

Dabo, S., Meurs, E.F., 2012. dsRNA-Dependent Protein Kinase PKR and its Role in Stress, Signaling and HCV Infection. Viruses 4, 2598-2635. https://doi.org/10.3390/v4112598

Der, S.D., Zhou, A., Williams, B.R., Silverman, R.H., 1998. Identification of genes differentially regulated by interferon alpha, beta, or gamma using oligonucleotide arrays. Proc. Natl. Acad. Sci. U. S. A. 95, 15623-15628.

Dey, M., Cao, C., Sicheri, F., Dever, T.E., 2007. Conserved Intermolecular Salt Bridge Required for Activation of Protein Kinases PKR, GCN2, and PERK. J. Biol. Chem. 282, 6653-6660. https://doi.org/10.1074/jbc.M607897200 
Doria, M., Neri, F., Gallo, A., Farace, M.G., Michienzi, A., 2009. Editing of HIV-1 RNA by the double-stranded RNA deaminase ADAR1 stimulates viral infection. Nucleic Acids Res. 37, 5848-5858. https://doi.org/10.1093/nar/gkp604

Elkhateeb, E., Tag-El-Din-Hassan, H.T., Sasaki, N., Torigoe, D., Morimatsu, M., Agui, T., 2016. The role of mouse 2',5'-oligoadenylate synthetase 1 paralogs. Infect. Genet. Evol. 45, 393-401. https://doi.org/10.1016/j.meegid.2016.09.018

Fierro-Monti, I., Mathews, M.B., 2000. Proteins binding to duplexed RNA: one motif, multiple functions. Trends Biochem. Sci. 25, 241-246. https://doi.org/10.1016/S09680004(00)01580-2

Garaigorta, U., Chisari, F.V., 2009. Hepatitis C Virus Blocks Interferon Effector Function by Inducing PKR Phosphorylation. Cell Host Microbe 6, 513-522. https://doi.org/10.1016/j.chom.2009.11.004

García, M.A., Meurs, E.F., Esteban, M., 2007. The dsRNA protein kinase PKR: Virus and cell control. Biochimie 89, 799-811. https://doi.org/10.1016/j.biochi.2007.03.001.

Guénet, J.L., Benavides, F., Panthier, J., Montagutelli, X., 2015. Genetics of the Mouse. Springer Berlin Heidelberg. XVII Chapters, 408 pages. https://doi.org/10.1007/978-3-66244287-6.

George, C.X., Samuel, C.E., 1999. Characterization of the 5'-flanking region of the human RNA-specific adenosine deaminase ADAR1 gene and identification of an interferon-inducible ADAR1 promoter. Gene 229, 203-213.

Ghosh, A., Sarkar, S.N., Guo, W., Bandyopadhyay, S., Sen, G.C., 1997. Enzymatic activity of 2'-5'-oligoadenylate synthetase is impaired by specific mutations that affect oligomerization of the protein. J. Biol. Chem. 272, 33220-33226.

Goodman, R.A., Macbeth, M.R., Beal, P.A., 2012. ADAR proteins: structure and catalytic mechanism. Curr. Top. Microbiol. Immunol. 353, 1-33. https://doi.org/10.1007/82_2011_144

He, X., Korytář, T., Zhu, Y., Pikula, J., Bandouchova, H., Zukal, J., Köllner, B., 2014. Establishment of Myotis myotis cell lines--model for investigation of host-pathogen interaction in a natural host for emerging viruses. PloS One 9, e109795. https://doi.org/10.1371/journal.pone.0109795

Herbert, A., Alfken, J., Kim, Y.-G., Mian, I.S., Nishikura, K., Rich, A., 1997. A Z-DNA binding domain present in the human editing enzyme, double-stranded RNA adenosine deaminase. Proc. Natl. Acad. Sci. U. S. A. 94, 8421-8426.

Justesen, J., Hartmann, R., Kjeldgaard, N.O., 2000. Gene structure and function of the 2'-5'oligoadenylate synthetase family. Cell. Mol. Life Sci. CMLS 57, 1593-1612.

Kim, Y.-G., Lowenhaupt, K., Schwartz, T., Rich, A., 1999. The Interaction between Z-DNA and the Zab Domain of Double-stranded RNA Adenosine Deaminase Characterized Using Fusion Nucleases. J. Biol. Chem. 274, 19081-19086. https://doi.org/10.1074/jbc.274.27.19081 
Kristiansen, H., Gad, H.H., Eskildsen-Larsen, S., Despres, P., Hartmann, R., 2011. The oligoadenylate synthetase family: an ancient protein family with multiple antiviral activities. J. Interferon Cytokine Res. Off. J. Int. Soc. Interferon Cytokine Res. 31, 41-47. https://doi.org/10.1089/jir.2010.0107

Lai, F., Drakas, R., Nishikura, K., 1995. Mutagenic Analysis of Double-stranded RNA Adenosine Deaminase, a Candidate Enzyme for RNA Editing of Glutamate-gated Ion Channel Transcripts. J. Biol. Chem. 270, 17098-17105. https://doi.org/10.1074/jbc.270.29.17098

Letunic, I., Doerks, T., Bork, P., 2015. SMART: recent updates, new developments and status in 2015. Nucleic Acids Res. 43, D257-260. https://doi.org/10.1093/nar/gku949

Levy, D.E., Marié, I., Smith, E., Prakash, A., 2002. Enhancement and diversification of IFN induction by IRF-7-mediated positive feedback. J. Interferon Cytokine Res. Off. J. Int. Soc. Interferon Cytokine Res. 22, 87-93. https://doi.org/10.1089/107999002753452692

Liu, Y., Samuel, C.E., 1996. Mechanism of interferon action: functionally distinct RNAbinding and catalytic domains in the interferon-inducible, double-stranded RNA-specific adenosine deaminase. J. Virol. 70, 1961-1968.

Malathi, K., Dong, B., Gale, M., Silverman, R.H., 2007. Small self-RNA generated by RNase L amplifies antiviral innate immunity. Nature 448, 816-819. https://doi.org/10.1038/nature06042

Malathi, K., Paranjape, J.M., Bulanova, E., Shim, M., Guenther-Johnson, J.M., Faber, P.W., Eling, T.E., Williams, B.R.G., Silverman, R.H., 2005. A transcriptional signaling pathway in the IFN system mediated by 2'-5'-oligoadenylate activation of RNase L. Proc. Natl. Acad. Sci. U. S. A. 102, 14533-14538. https://doi.org/10.1073/pnas.0507551102

Mannion, N., Arieti, F., Gallo, A., Keegan, L.P., O’Connell, M.A., 2015. New Insights into the Biological Role of Mammalian ADARs; the RNA Editing Proteins. Biomolecules 5, 2338-2362. https://doi.org/10.3390/biom5042338

Marié, I., Blanco, J., Rebouillat, D., Hovanessian, A.G., 1997. 69-kDa and 100-kDa isoforms of interferon-induced (2'-5')oligoadenylate synthetase exhibit differential catalytic parameters. Eur. J. Biochem. 248, 558-566.

McCormack, S.J., Ortega, L.G., Doohan, J.P., Samuel, C.E., 1994. Mechanism of Interferon Action Motif I of the Interferon-Induced, RNA-Dependent Protein Kinase (PKR) Is Sufficient to Mediate RNA-Binding Activity. Virology 198, 92-99. https://doi.org/10.1006/viro.1994.1011

Meurs, E., Chong, K., Galabru, J., Thomas, N.S.B., Kerr, I.M., Williams, B.R.G., Hovanessian, A.G., 1990. Molecular cloning and characterization of the human doublestranded RNA-activated protein kinase induced by interferon. Cell 62, 379-390. https://doi.org/10.1016/0092-8674(90)90374-N 
Meurs, E.F., Watanabe, Y., Kadereit, S., Barber, G.N., Katze, M.G., Chong, K., Williams, B.R., Hovanessian, A.G., 1992. Constitutive expression of human double-stranded RNAactivated p68 kinase in murine cells mediates phosphorylation of eukaryotic initiation factor 2 and partial resistance to encephalomyocarditis virus growth. J. Virol. 66, 5805-5814.

Moratelli, R., Calisher, C.H., 2015. Bats and zoonotic viruses: can we confidently link bats with emerging deadly viruses? Mem. Inst. Oswaldo Cruz 110, 1-22. https://doi.org/10.1590/0074-02760150048

Pulit-Penaloza, J.A., Scherbik, S.V., Brinton, M.A., 2012. Activation of Oas1a gene expression by type I IFN requires both STAT1 and STAT2 while only STAT2 is required for Oas $1 \mathrm{~b}$ activation. Virology 425, 71-81. https://doi.org/10.1016/j.virol.2011.11.025

Saraste, M., Sibbald, P.R., Wittinghofer, A., 1990. The P-loop--a common motif in ATP- and GTP-binding proteins. Trends Biochem. Sci. 15, 430-434.

Sarkar, S.N., Miyagi, M., Crabb, J.W., Sen, G.C., 2002. Identification of the substrate-binding sites of 2'-5'-oligoadenylate synthetase. J. Biol. Chem. 277, 24321-24330. https://doi.org/10.1074/jbc.M110202200

Sarkis, S., Lise, M.-C., Darcissac, E., Dabo, S., Falk, M., Chaulet, L., Neuveut, C., Meurs, E.F., Lavergne, A., Lacoste, V., 2018. Development of molecular and cellular tools to decipher the type I IFN pathway of the common vampire bat. Dev. Comp. Immunol. 81, 1-7. https://doi.org/10.1016/j.dci.2017.10.023

Sen, G.C., 2001. Viruses and Interferons. Annu. Rev. Microbiol. 55, 255-281. https://doi.org/10.1146/annurev.micro.55.1.255

Shaw, A.E., Hughes, J., Gu, Q., Behdenna, A., Singer, J.B., Dennis, T., Orton, R.J., Varela, M., Gifford, R.J., Wilson, S.J., Palmarini, M., 2017. Fundamental properties of the mammalian innate immune system revealed by multispecies comparison of type I interferon responses. PLOS Biol. 15, e2004086. https://doi.org/10.1371/journal.pbio.2004086

Silverman, R.H., 2003. Implications for RNase L in Prostate Cancer Biology. Biochemistry (Mosc.) 42, 1805-1812. https://doi.org/10.1021/bi027147i

Tag-El-Din-Hassan, H.T., Sasaki, N., Moritoh, K., Torigoe, D., Maeda, A., Agui, T., 2012. The chicken 2'-5' oligoadenylate synthetase A inhibits the replication of West Nile virus. Jpn. J. Vet. Res. 60, 95-103.

Tamura, K., Stecher, G., Peterson, D., Filipski, A., Kumar, S., 2013. MEGA6: Molecular Evolutionary Genetics Analysis version 6.0. Mol. Biol. Evol. 30, 2725-2729. https://doi.org/10.1093/molbev/mst197

Williams, B.R.G., 2001. Signal Integration via PKR. Sci STKE 2001, re2-re2. https://doi.org/10.1126/stke.2001.89.re2

Xiang, Y., Wang, Z., Murakami, J., Plummer, S., Klein, E.A., Carpten, J.D., Trent, J.M., Isaacs, W.B., Casey, G., Silverman, R.H., 2003. Effects of RNase L mutations associated with prostate cancer on apoptosis induced by 2',5'-oligoadenylates. Cancer Res. 63, 6795-6801. 
583 Yamamoto, Y., Sono, D., Sokawa, Y., 2000. Effects of specific mutations in active site motifs 584 of 2',5'-oligoadenylate synthetase on enzymatic activity. J. Interferon Cytokine Res. Off. J. 585 Int. Soc. Interferon Cytokine Res. 20, 337-344. https://doi.org/10.1089/107999000312496

Zhou, P., Cowled, C., Wang, L.-F., Baker, M.L., 2013. Bat Mx1 and Oas1, but not Pkr are highly induced by bat interferon and viral infection. Dev. Comp. Immunol. 40, 240-247. https://doi.org/10.1016/j.dci.2013.03.006

Zhou, P., Tachedjian, M., Wynne, J.W., Boyd, V., Cui, J., Smith, I., Cowled, C., Ng, J.H.J., Mok, L., Michalski, W.P., Mendenhall, I.H., Tachedjian, G., Wang, L.-F., Baker, M.L., 2016. Contraction of the type I IFN locus and unusual constitutive expression of IFN- $\alpha$ in bats. Proc. Natl. Acad. Sci. U. S. A. 113, 2696-2701. https://doi.org/10.1073/pnas.1518240113 
597 species. The two important signature domains, NTP-transf_2 and OAS1_C in D. rotundus

598 OAS1a and OAS1b are highlighted with solid arrows. Amino acid sequence motifs important 599 for the enzyme activity are shown in boxes. The orange rectangle represents the Serine 600 residue in the putative helical turn, the adjacent Serine, which is either Serine or Threonine 601 (Rune Hartmann et al., 2003 Molecular cell). Inverted triangle: one of the signature features 602 of the nucleotidyl transferase superfamily is a conserved triad of aspartic acids predicted to 603 coordinate the catalytically active magnesium ions. The multi-alignment was performed with 604 the ClustalW program using default parameters. Dashes indicate gaps in the amino acid

605

606

607

608

609

610

611

612

613

614

615

616

617

618

619

620

alignment. Abbreviations: MlOAS1: Myotis lucifigus OAS1 (XM_014464612), MIOAS11: Myotis lucifigus OAS1-like (XM_014462497), HsOAS1: Homo sapiens OAS1 (BC000562),

SsOAS1: Sus scrofa (NM_214303), MmOAS1a-h: Mus musculus OAS1a-h (XM_006530330, BC012877, NM_033541, BC052835, BC053721, BC116433, BC018470, NM_145228).

Figure 2. Amino acid alignments of $D$. rotundus ADAR1 and PKR with their homologs from other mammalian species. a) All motifs required for ADAR1 activity are highlighted with solid arrows, including two Z $\alpha$ domains at the N-terminus, followed by three doublestranded RNA-binding motifs (dsRBM), dsRBM1, 2 and 3, and a catalytic deaminase domain at its C-terminus. b) PKR contains two dsRBM highlighted in yellow (dsRBM1) and light gray (dsRBM2) followed by a basic region (dark gray) and subdomain sequences in boxes found in the catalytic region highlighted with solid arrows, green represents the repeat sequence in human PKR not present in D. rotundus, other bat species and mice PKR. An insert region at the C-terminal of the subdomain IV is highlighted in blue. The multialignments were performed with the ClustalW program using default parameters. Dashes indicate gaps in the amino acid alignments. Abbreviations: PaADAR1/PKR: Pteropus alecto 
ADAR1/PKR (XM_015598363/NM_0012910168), HsADAR1/PKR: Homo sapiens ADAR1/PKR (NM_001111/XM_011532987), MmADAR1/PKR: Mus musculus $\quad$ ADAR1/PKR (NM_019655/NM_011163).

Figure 3. Phylogenetic trees generated from amino acid sequence alignments of OAS1, ADAR1 and PKR from D. rotundus and other mammals. Phylogenetic trees were generated based on (a) the alignment of partial amino acid sequence of the mammalian OAS1, and the full-length protein sequence of (b) ADAR1 and (c) PKR. The trees were inferred using the Bayesian method with the JTT + G model. Sequence identifiers include the NCBI accession number. Posterior probabilities of the Bayesian analysis ( $>50 \%)$ are shown next to each node. The scale bar indicates amino acid substitutions per site.

Figure 4. Poly(I:C) transfection induces expression of ISGs. Time-course fold induction of (a) OAS1a, (b) OAS1b, (c) ADAR1 and (d) PKR in FLuDero cells upon poly(I:C) transfection. ISGs mRNA were assessed by RTqPCR. Data were normalized against $\beta$-actin. Cells were stimulated with $20 \mu \mathrm{g} / \mathrm{mL}$ of poly(I:C) and harvested at the indicated time points. Data represent the mean values of three separate experiments, and the error bars represent standard deviations (SD).

Figure 5. Quantitative mRNA expression of OAS1a, OAS1b, ADAR1 and PKR. Time course mRNA expression levels of (red) OAS1a, (green) OAS1b, (blue) ADAR1 and (purple) PKR were assessed by RTqPCR in FLuDero cells upon poly(I:C) transfection. Cells were stimulated with $20 \mu \mathrm{g} / \mathrm{mL}$ of poly(I:C) and harvested at the indicated time points. The expression was normalized to the housekeeping gene $\beta$-actin. Data represent the mean values of three separate experiments. 

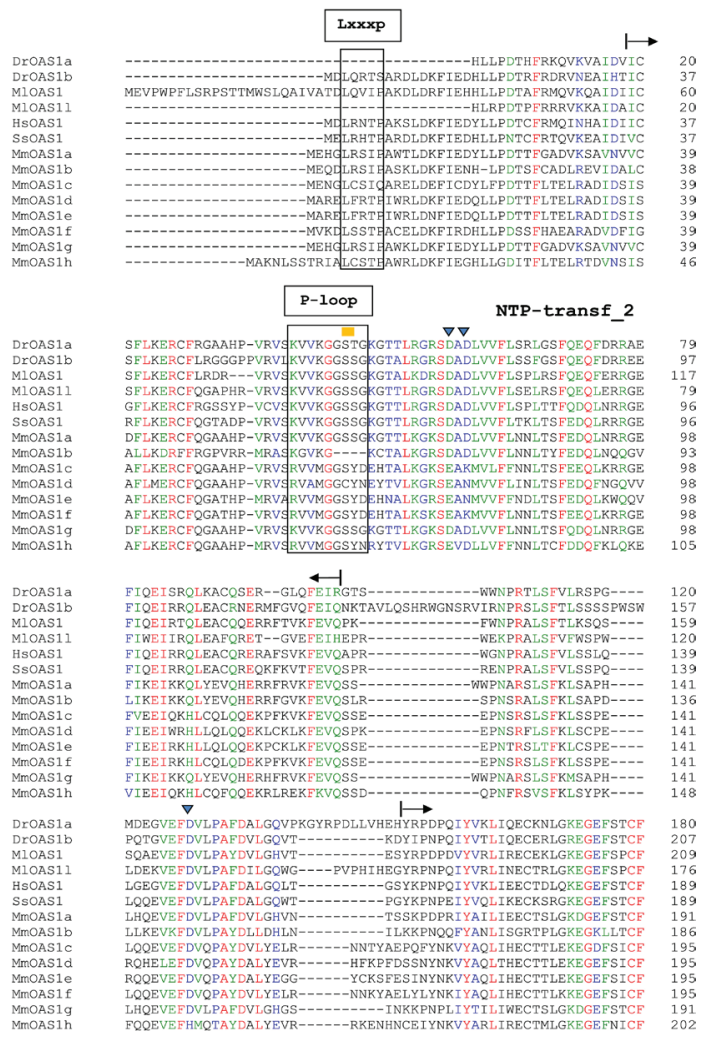

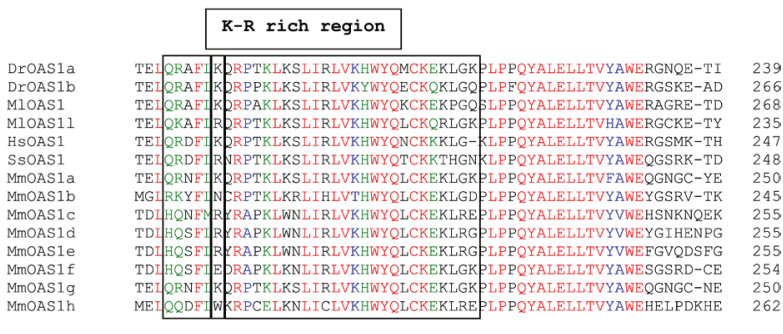

OAS1_C
DYOAS1a FSTAQGEQTVLELVYNYQQLLI YWTKYYDEENPVIGQYLRMQLKKPRPVILDPADPTGNV FITAQGERTVLELVMNYRQLCI HWTQYYDCSHPE IGPYVRRQIQRPRPVILDPADPTGNV
FSTAEGERTVLELVVHYRQICVYWTKYYDEENPVICOYLMTQIEQPMPVILDPADPTGNV FSTAQGEQTVLELVLKHOKLCI FWEAYY DETNPVVGRCMLQQLKKPRPVILDPADPTGNV FNTAQGERTVLELVTKYKOTRTYWTYYDERHEEVSEYHHOQTKRDRPVTIDPADPTRNT VTTAKNFRTELELVAYYKNLRIYWTWYYDFRHQEVCAYLCRQIKKARPLILDPADPTRNV LHAQCFA FNTAQGERTVIETVTKYKWT RTYWTVYYDERKTKVSEYT HKMT OKVPPVTIDPADPTRNY FNTAQGERTVLELVINYQHLRIYWTKYYDEQHKEVSKYLHRQIRKARPVILDPADPTGNV
TQTARGERTVLELITKYICLRIYWTLYYDVLHEQVNAYLYSQVKRVSPLILDPADPTWNV

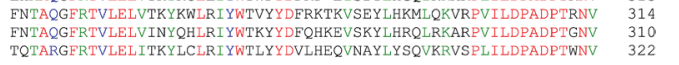




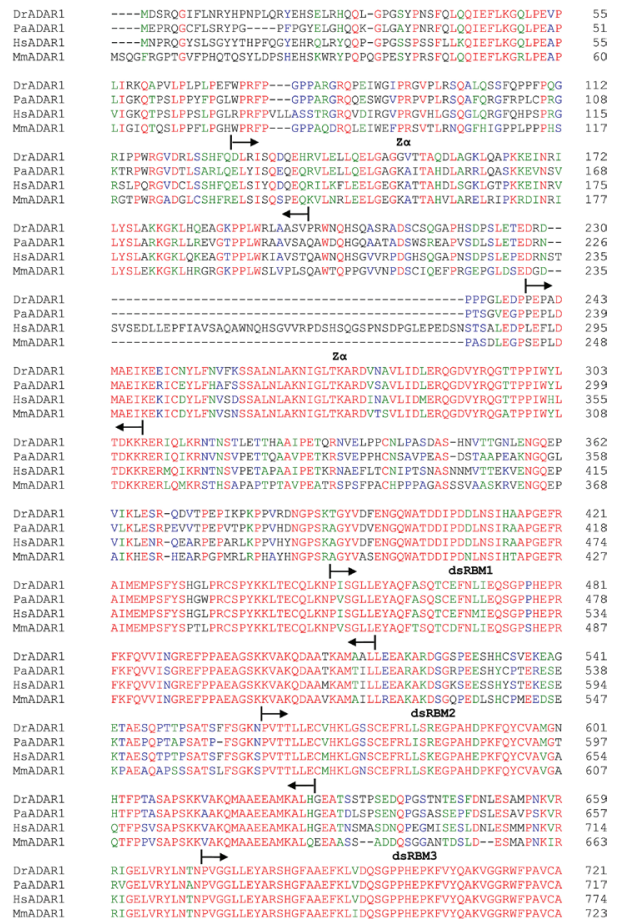

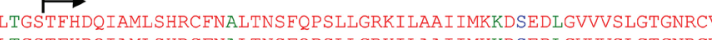
LTGSTFHDQ IAMLSHRCFNALTNSFQPSLLGRKI LAAI IMKKDSE DLGVVVSLGTGNRCV LTGSTFHDQIAMLS HRCFNTLTNSFQPSLLGRKILAAI IMKKDSE DMGVVVSLGTGNRC LSGSTFHDQIAMLSHRCFNALTNSFQPSLIGRKILAAI IMKRDPEDMGVVVSLGTGNRCV

KGDSLSLKGETVNDCHAEI ISRRGF IRF LYNEIMKYSPQTAKDS IFEPARGGEKLQIKKT KGDSLSLKGETVNDCHAEI I SRRGF I RFLYSELMKYNPQTAKDS I FEPAKGGEKLQIKK KGDSLSLKGETVNDCHAEIISRRGF IRFLYSELMKYNSQTAKDSIFEPAKGGEKLQIKK KGDS LSLKGETVNDCHAE I ISRRGE I RF LY SELMKYNHHTAKNS I FELARGGEKLQIKKT

VSFHLYISTAPCGDGALFDKSCSDRAVESTDSRHYPVEENPKQGKLRTKVENGEGTIPVE VSFHLYISTAPCGDGALFDKSCSDRAVESTDPRHYPVFENPKQGKLRTKVENGEGTIPVE VSFHLYISTAPCGDGALFDKSCSDRAMESTESRHY PVFENPKQGKLRTKVENGEGTIPVE
VSFHLYISTAPCGDGALFDKSCSDRAVESTESRHYPVFENPKQGKLRTKVENGEGTIPVE

VSFHLYISTAPCGDGALFDKSCSDRAVESTESRHYPVFENPKQGKLRTKVENGEGTIPVE
catalytic deaminase domain
SSDIVPTWDGIRLGERLRTMSCSDKI LRWNVLGLGALLTHFLQVYLKSVTLGYLFSQG
SSDIVPTWDGIRLGERLRTMSCSDKILCWNVLGLOGALLTHFLQPVYLKSVTLGYLFSOG

HSADAR

MmADAR

DIADARI

PAADAR1 SSDIVPTWDGIRLGERLRTMSCSDKI LCWNVLGLQGALLTHFLQPVYLKSVTLGYLFSOC $\begin{array}{lr}\text { SSDIVPTWDGIRLGERLRTMSCSDK I LRWNVLGLQGALLTHFIQPIYLKSVTLGYLFSQG } & 1074 \\ \text { SSDIVPTWDGIRLGERLRTMSCSDKI LRWNVLGLQGALLTHFLQPVYLKSVTLGYLFSQG } & 997\end{array}$

MADART

$\begin{array}{lll}\text { DrADAR1 } & \text { HLTRAICCRVTRDGSAFEDGLRHPF IVNHPKVGRVSVYDSKRQSGKTKETSVNWCLADGY } & 1055 \\ \text { PaADAR1 } & \text { HLTRAICCRVTRDGSAFEDGLOPPFTVNHPKVGRVSVYDSKRQSGKTKETSVNWCLADGC } & 1051\end{array}$

$\begin{array}{lll}\text { HSADAR1 } & \text { HLTRAICCRVTRDGSAFEDGLRHPF IVNHPKVGRVSIYDSKRQSGKTKETSVNWCLADGY } & 1134 \\ \text { MmADAR1 } & \text { HLTRAICCRVTRDGKAFEDGLRYPF IVNHPKVGRVSVYDSKRQSGKTKETSVNWCMADGY } & 1057\end{array}$

DIADAR1 DLEILDGTRGTVDGPRNELSRVSKKNIFLLFKRLCSFRARRDLLKLSYGEAKKAARDYET 1115 PaADAR1 DLEILDGTRGTVDGPRSELSRVSKKNIFLIFKKLCSFRGRRDLLKLSYGEAKKAARDYEA 1111 $\begin{array}{lll}\text { HSADAR1 DLEILDGTRGTVDGPRNELSRVSKKNIFLLFKKLCSFRYRRDLLRLSYGEAKKAARDYET } & 1194 \\ \text { MMADAR1 } & \text { DLEILDGTRGTVDGPGKELSRVSKKNIFLQFKKLCSFRARRDLLQLSYGEAKKAARDYDL } & 1117\end{array}$ $\begin{array}{ll} & \\ \text { AKNYFKKSLKDMGYGNWISKPQEEKNEYLCPV } & 1147 \\ \text { AKNYFKKGLKDMGYGNWISKPQEEKNFYLCPV } & 1143 \\ \text { AKNYFKKGLKDMGYGNWISKPQEEKNFYLCPV } & 1226 \\ \text { AKNYFKKSLRDMGYGNWISKPQEEKNFYCPV } & 1149\end{array}$ 


\begin{tabular}{|c|c|}
\hline $\begin{array}{l}\text { DrPKR R } \\
\text { PaPRR } \\
\text { HsPKR }\end{array}$ & 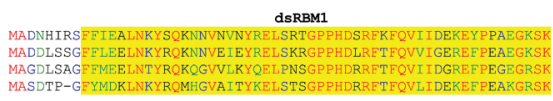 \\
\hline $\begin{array}{l}\text { PKR } \\
\text { PKR } \\
\text { PKR } \\
\text { PKR }\end{array}$ & 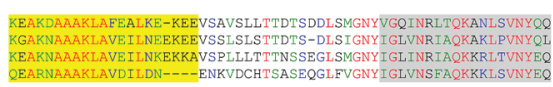 \\
\hline $\begin{array}{l}\text { DPFRR } \\
\text { FaPKR } \\
\text { atsPKR }\end{array}$ & 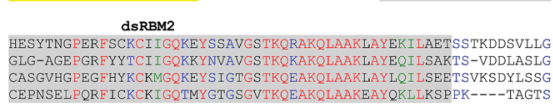 \\
\hline $\begin{array}{l}\text { DrPKR } \\
\text { PaPKR } \\
\text { HsPKR } \\
\text { YmPKR }\end{array}$ & 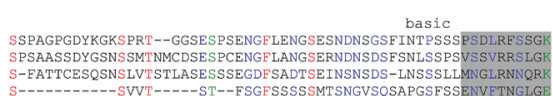 \\
\hline PKR & 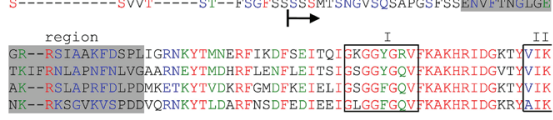 \\
\hline $\begin{array}{l}\text { PrPKR } \\
\text { PaPKR } \\
\text { PaPKR } \\
\text { ImPRR }\end{array}$ & 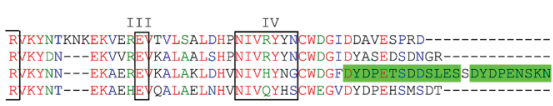 \\
\hline $\begin{array}{l}\text { DrPKR } \\
\text { PaPKR } \\
\text { HISPKR } \\
\text { MmPKR }\end{array}$ & 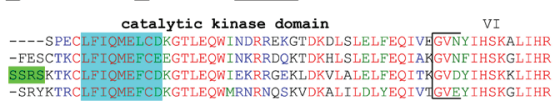 \\
\hline $\begin{array}{l}\text { PrPKR } \\
\text { PaPKR } \\
\text { AlPRR } \\
\text { smPKR }\end{array}$ & 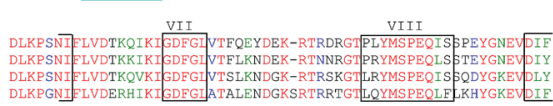 \\
\hline $\begin{array}{l}\text { DrPKR } \\
\text { PaPKR } \\
\text { HsPKR } \\
\text { MmPKR }\end{array}$ & 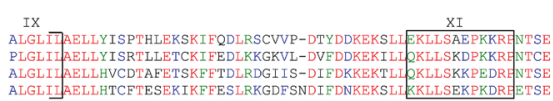 \\
\hline 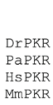 & 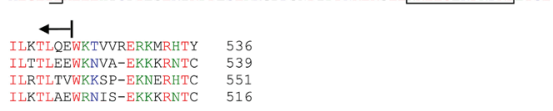 \\
\hline
\end{tabular}

Figure 2. 

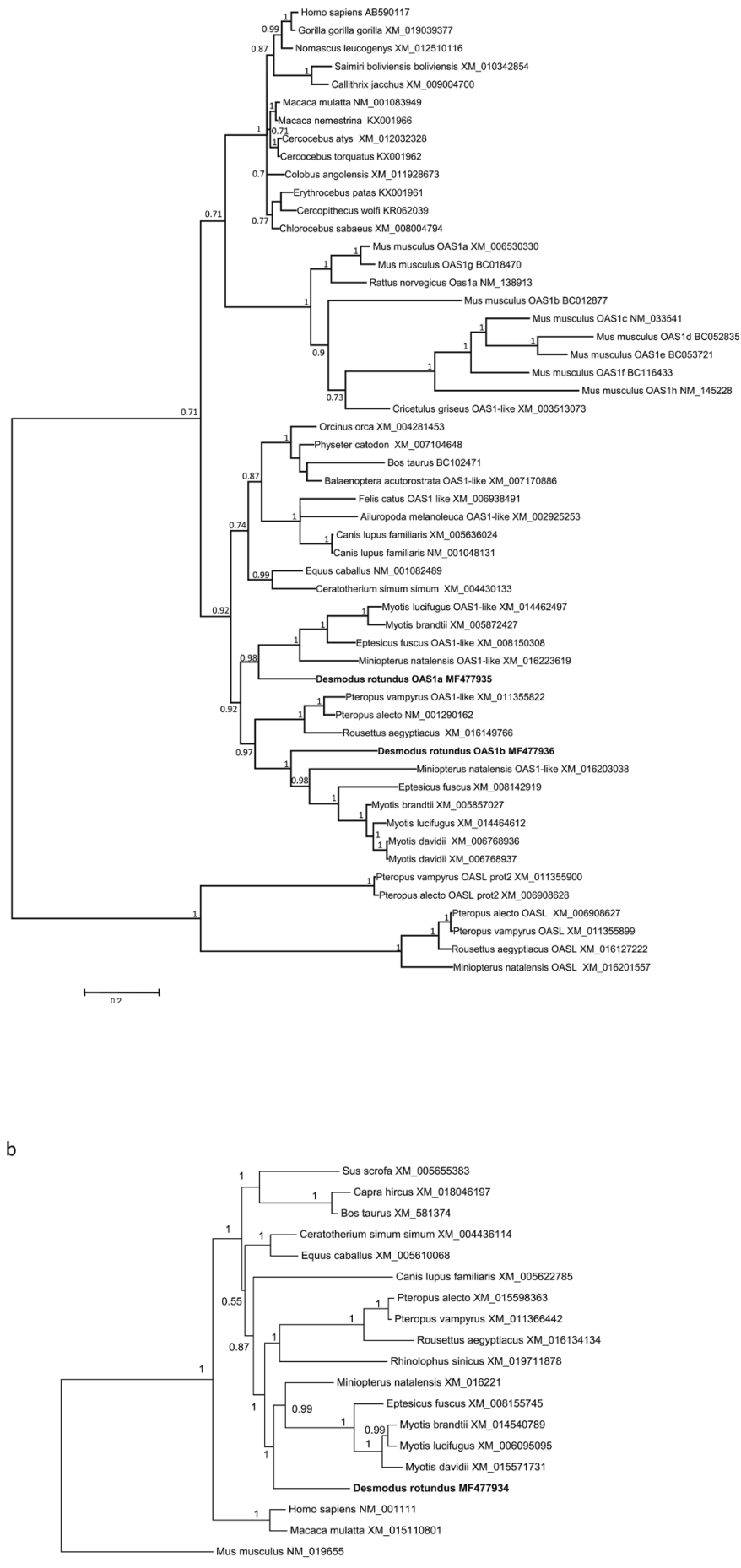

0.05

C

Figure 3.

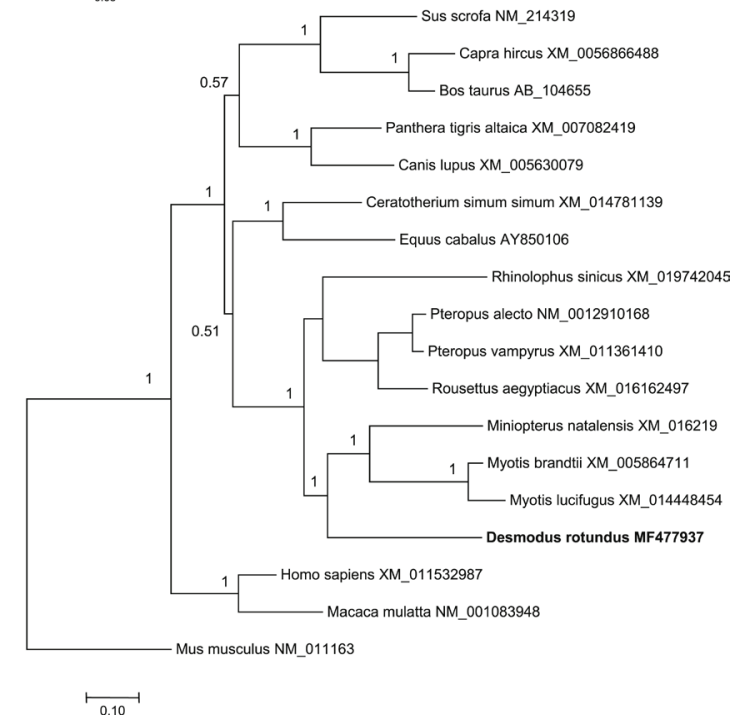




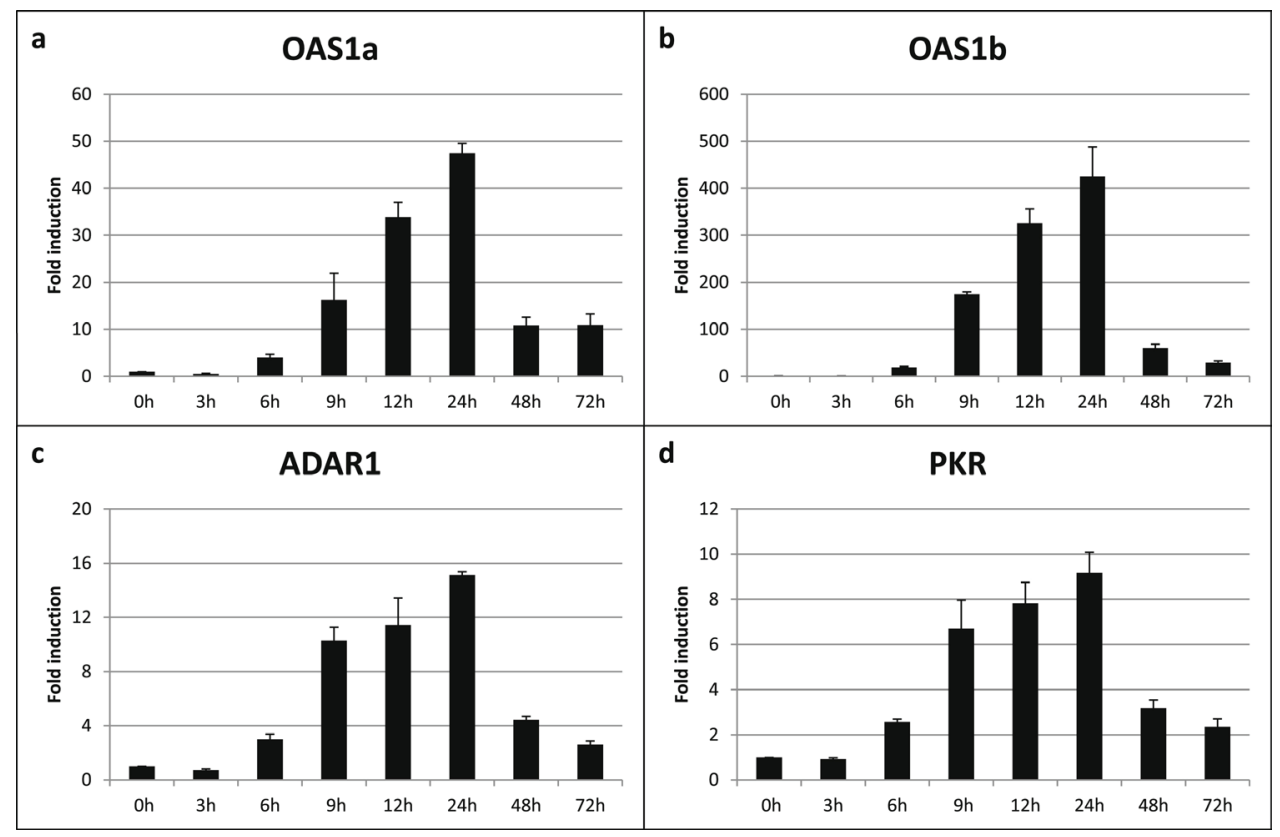

Figure 4 .

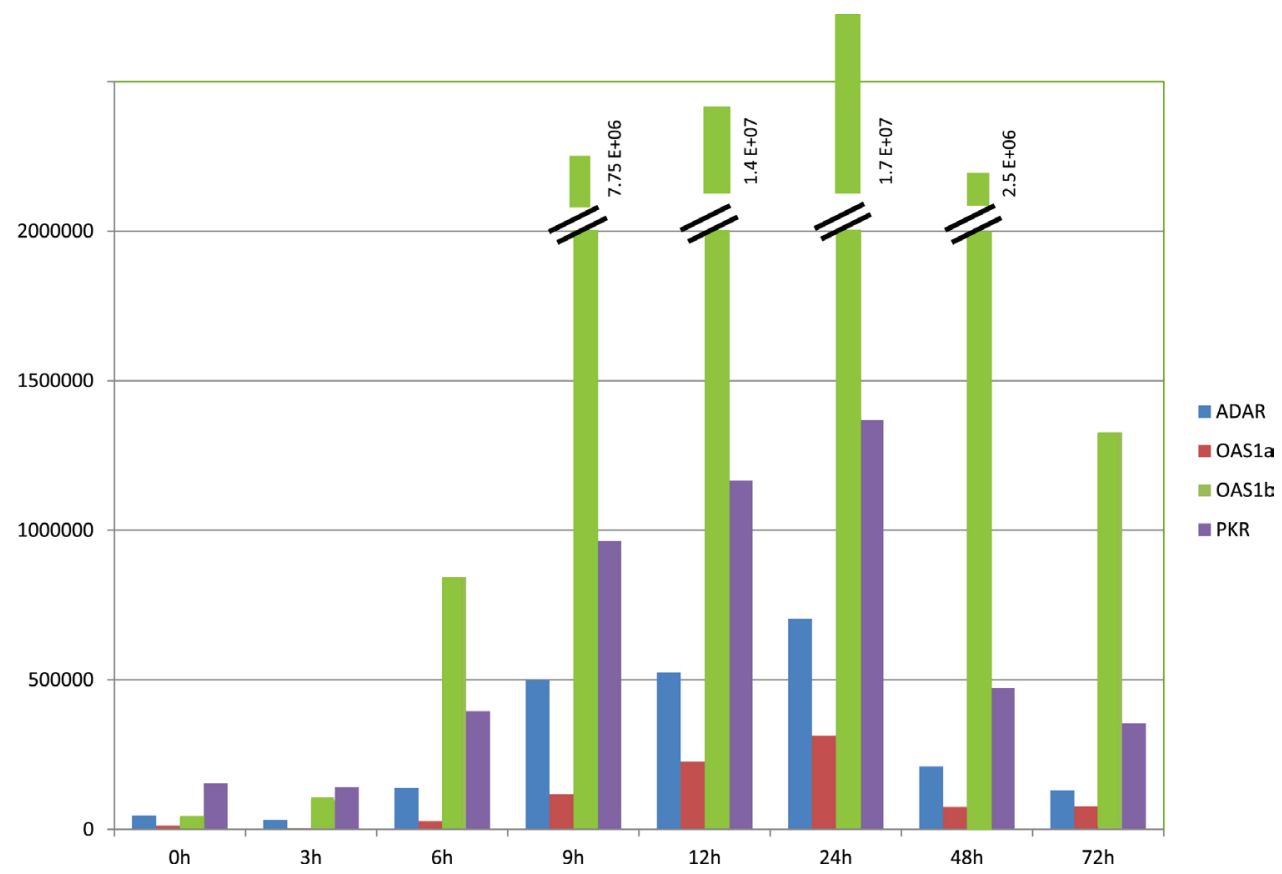

Figure 5. 